$\stackrel{N / 2}{N}$

Global Journals Inc

(2)

\title{
Is Indian Equity Options Market Suitable for Hedging when the Options Pay off Structure Changes?
}

By James Varghese \& Dr. Babu Jose

St. Thomas College, Palai

Abstract- Investments are essential as the growth of the stock market denoted through increased investments results in the growth of the economy. But they are always subject to various risks in the market. These risks are to be mitigated for the development of an efficient economic system by the market itself. Apart from the stock segment, the Indian financial market is a home for futures and options segments that facilitate the hedging of risks involved in the investments. For considering any derivative market as a hedging tool, one of the prerequisites is the presence of integration between such derivative market and its underlying market. The present study focuses on testing the relationship between Indian stock market and the options market, represented by NSE Nifty 50 index and index options on it respectively, to know whether the options segment is suitable for hedging the risks implicit with investments in the stock market, with substantial consideration to payoff structure of the market denoted by different moneyness groups viz. Keywords: stock market efficiency, informational efficiency, call options, put options, implied index level, cointegration, error correction model, options payoff structure, options moneyness, hedging, NSE nifty 50.

GJMBR-B Classification: JEL Code: G19

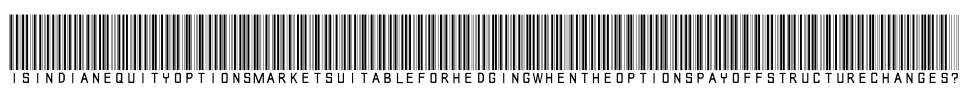

Strictly as per the compliance and regulations of:

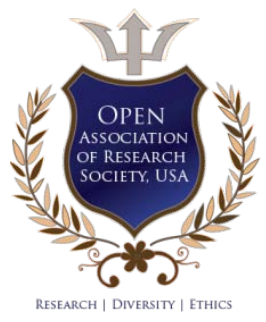

(C) 2020. James Varghese \& Dr. Babu Jose. This is a research/review paper, distributed under the terms of the Creative Commons Attribution-Noncommercial 3.0 Unported License http://creativecommons.org/licenses/by-nc/3.0/), permitting all noncommercial use, distribution, and reproduction in any medium, provided the original work is properly cited. 


\title{
Is Indian Equity Options Market Suitable for Hedging when the Options Pay off Structure Changes?
}

\author{
James Varghese $^{\alpha} \&$ Dr. Babu Jose ${ }^{\sigma}$
}

\begin{abstract}
Investments are essential as the growth of the stock market denoted through increased investments results in the growth of the economy. But they are always subject to various risks in the market. These risks are to be mitigated for the development of an efficient economic system by the market itself. Apart from the stock segment, the Indian financial market is a home for futures and options segments that facilitate the hedging of risks involved in the investments. For considering any derivative market as a hedging tool, one of the prerequisites is the presence of integration between such derivative market and its underlying market. The present study focuses on testing the relationship between Indian stock market and the options market, represented by NSE Nifty 50 index and index options on it respectively, to know whether the options segment is suitable for hedging the risks implicit with investments in the stock market, with substantial consideration to payoff structure of the market denoted by different moneyness groups viz. at-the-money, in-the-money, out-ofthe-money, deep-in-the-money and deep-out-of-the-money, for the period from June 2001 to March 2019. This study is an extension of the empirical literature that investigated the efficiency of the stock market and the informational efficiency of the options market. After deriving time-series for call and put options in each moneyness categories from multiple contracts belonging to each class for the same trading day, econometric models including Johansen's co integration and vector error correction model are used to identify the integration and the lead-lag structure among the stock market and options segments, to know whether the hedging mechanism is possible in the options market. The study draws that the Indian equity options market is suitable for hedging, and the relative rapidity of information absorption proves that it is 'informational efficient'. Finally, the study concludes that the options pay off structure has a significant role in making the market informational efficient.
\end{abstract}

Keywords: stock market efficiency, informational efficiency, call options, put options, implied index level, cointegration, error correction model, options payoff structure, options moneyness, hedging, NSE nifty 50.

\section{InTRODUCTION}

T he ability to be exercised at the sole discretion of the holder keeps the options most dynamic, among other derivative instruments (Hull \& Basu, 2016). Moreover, similar to any other derivative instruments, the options market also stands for the vital

Author a $\sigma$ : Assistant Professor, Department of Commerce St. Thomas College, Palai, Arunapuram P.O., Kottayam, Kerala, India.

e-mails: jvstcp@gmail.com, babujoset@gmail.com purposes of price discovery, hedging, speculation and arbitrage, and focuses on facilitating optimum satisfaction of capital requirements in the economy (Ammann \& Herriger, 2002; Dixit, Yadav, \& Jain, 2009). All the above fundamental functions of derivative markets are complementary and interconnected. The uses of options market by the market participants, viz. hedging, speculation and arbitrage are facilitated by the price discovery process. Price discovery is the process of incorporating all the available information into the current price level in the market to arrive at an equilibrium price (Booth, So, \& Tse, 1999). While comparing both the derivatives and their underlying assets, the knowledge on the market that leads in the price discovery process is of enormous value to the market participants, as it helps in anticipating the price movements in both the segments. From a macroeconomic perspective, the efficiency of the capital and allied financial markets are also of keen importance as it indicates the trend in the growth of the economy (Jain, Vyas, \& Roy, 2013). The capital market is efficient when the market, inherently, does not allow the participants to make abnormal gains from the transactions in it(Fama, 1970). Market efficiency is possible only when the entire available information is used efficiently by all the market participants instantaneously (Black \& Scholes, 1972). Abnormal profits are of little probability from an efficient market as all the information is absorbed and disseminated in the market and instantly reflected in the prices of securities (Khan, Ikram, \& Mehtab, 2011). Therefore, the study of the price discovery is an investigation into the market efficiency as well, since it looks for the extent of simultaneity among connected financial markets in absorbing the information to reflect the same in the prices, leaving no further arbitrage possibilities to be explored.

Since the intention of options market is to facilitate hedging the risks involved in the investment in the underlying assets, the concept of informational efficiency becomes significant. Informational efficiency stands for the relative speed of reflection of the information in different related markets, as represented by the changes in the price level. The options market is informational efficient compared to the stock market when it is capable of reflecting the information relatively faster than the other markets. This relative speed of 
adjustment causes lead-lag structure among the related markets, which is based on the idea that price changes due to the new information occur first in a fairly efficient market than others. Thus, the speed of adjustment to the new information indicates the relative informational efficiency of the markets. In other words, the presence of lead-lag relationship shows the informational inefficiency of the related markets. When the markets are efficient, due to the instantaneous reflection of the information in related markets, arbitrage opportunities do not exist and even if they exist, they cause the price discrepancies in related markets to be disappeared (Chan, Chung, \& Johnson, 1993). The absence of this simultaneous integration of information causes lead-lag relationships between different financial markets and results in arbitrage profits to the extent that the lead-lag influences outweigh the transaction costs (Hentze \& Seiler, 2000). Thus, the literature on exploration of the lead-lag association among allied markets extends to informational efficiency, which denotes simultaneous and chockfull reflection of information among markets. The market efficiency is also related to the predictability of the prices (Joshi, 2012), as predictable market returns questions this efficiency (Dicle, Beyhan, \& Yao, 2010). The efficient market hypothesis puts forward that beating the market is impossible when it is efficient. But, a large number of investors believe that there exists exploitable disequilibrium between information in financial markets and the prices of securities (Stakic, Jovancai, \& Kapoor, 2016). Thus, the empirical studies on market efficiency include tests for return predictability, event studies and tests for private information (Oprean, 2012).

There are different reasons for the success of the options market, among other derivatives markets. They are the ability to hedge, to speculate and to make arbitrage profits, reduction of costs to investors, provision of leverage to investors and effect of removal of stock market restrictions on the short-sale. But, having a fixed maturity makes options riskier. Moreover, there is faster execution of options contracts on the trading floor. These factors make the options market more attractive and thus cause lead-lag relationship between the options market and the underlying or allied markets (Hentze \& Seiler, 2000). The empirical literature existing in the options market on price discovery, informational efficiency and cross-market efficiency (Caralla \& Mammola, 2000; Ammann \& Herriger, 2002) gives inconclusive evidence. The research on relative price discovery in related markets also results in the same (Hentze \& Seiler, 2000; Srivastava, 2004; Gupta \& Basu, 2007; Amadori, Bekkour, \& Lehnert, 2014). Apart from the above theoretical explanations, there is an argument that the options segment in developing markets is not suitable for hedging (Bakshi, Cao, \& Chen, 2000). As far as the options market is concerned, there are large numbers of options contracts being traded on a single underlying asset, based on differences in time to expiration and strike prices. The changes in strike prices lead to the formation of different groups of moneyness which determines the payoff structure of options. Considering the above, the purpose of this paper is to examine the suitability of the Indian options market in hedging the investments in the underlying stock market effectively using options contracts falling under different moneyness categories. The derivative markets are useful for hedging the risk involved in the underlying spot market only when the theoretical presumption of integration among both the markets stands true. Therefore, the current study focuses on investigating the informational efficiency of the Indian equity options market in terms of its integration with the underlying spot market. The relative informational efficiency is investigated, in such a way that the results of the same would be constructive for market participants who approach the options market for hedging, by assisting them to exploit anticipative market movements.

For an in-depth analysis, the data has been analyzed under all the five moneyness categories viz. atthe-money (hereafter, ATM), in-the-money (hereafter, ITM), out-of-the-money (hereafter, OTM), deep-in-themoney (hereafter, DITM) and deep-out-of-the-money (hereafter, DOTM), and also for both call options and put options. In all phases, price series in both the markets are non stationary and the results from Johansen's cointegration procedure and Vector Error Correction Model (VECM) conclude that the stock market and options market are integrated, and the options segments absorb all information effectively than the underlying market does.

The rest of the paper include part two that summarizes the existing literature on different areas under consideration, part three that explains the empirical methodology used, part four that contains description of the data followed by discussion on empirical results in part five and part six that concludes the paper.

\section{Review OF Literature}

The economic incentives attached to options trading are lower transaction costs and higher leverage, liquidity and flexibility (Harvey \& Whaley, 1992; Kumar, Sarin, \& Shastri, 1995; Fleming, Ostdick, \& Whaley, 1996; Easley, O'Hara, \& Sreenivas, 1998; Hentze \& Seiler, 2000; Chakravarthy, Gulen, \& Mayhew, 2004). Even though it is a hedging tool, due to the above incentives, trade volume and incidence of trade is more in the options market. Therefore, as theory says, the options market may absorb the currently available information in the market, and it may create a leading effect in the options market when compared to the stock segment. 
A study among 25 firms in the USA during the early 1980s considering the trade volume as the indicator proved that the options trade volume leads the stock trade volume and thus options market lead the stock market (Anthony, 1988). This evidence goes in line with the findings of Manaster and Rendleman (1982) and Bhattacharya (1987) in the early literature. Fleming, Ostdick, and Whaley (1996) proved that stock index options led the stock index, consistent to the trading cost hypotheses, but proved otherwise in case of stocks. Amin and Lee (1997) investigated the informational role of equity options market in price discovery in times of dissemination of earnings news in the equity market and showed the presence of abnormal trade volume in the options market during days before the announcements and proved that private information was available with options traders. Further, it was noted that the options market anticipated the direction of the underlying market and the price discovery happened in the derivative segment. Conover and Peterson (1999) conducted an extensive analysis of the lead-lad structure in the relationship between the stock market and its options segments, taking earnings surprises, nature of the news, viz. positive and negative and changes in the regulatory environment in the USA. Their findings were that in the pre-regulation era, the options market led the stock market for negative news. Mazouz, $\mathrm{Wu}$, and Yin (2015), while examining the trading activity in stocks and options around price-sensitive announcements, also found out that informed traders prefer to trade in the options market, in times of negative news. The assumption that the stock market and options market are related market stands as the basis for the studies on the comparative informational efficiency of both the markets. Kumar, Sarin, and Shastri (1995) empirically tested this relationship in Japan around the period of listing of Nikkie index options. Scrutinizing the pre-listing and post-listing data, they found that the introduction of derivative securities caused a reduction in speculative and informationbased trading in the underlying market. Boyle, Byoun, and Park (2002) also supported the arguments of price discovery in the derivative markets and proved that the S\&P 500 index options market was leading the stock market. Ryu (2016) suggested the investors to postpone their trades to avoid transacting with better-informed traders when the market turns active, characterized by fast and large transactions with dried liquidity. When informed investors choose to use options, it becomes a reservoir of rich information on future stock prices. Lee and Wang (2016) tested the predictive ability of options volume, and found that the trade volume by foreign institutional investors contained rich information relating to future changes in the index, whereas transactions by others were found uninformative, in Taiwan index options market.
Since much empirical literature disprove the theoretical expectation that price discovery should occur in the options market compared to the stock market, using Hasbrouk's (1995) information share methodology, Chakrav arty, Gulan, and Mayhew (2004) noted that the options market tended to be more informative on an average when options trading volume was high, when stock trading volume was low, when option effective spreads were narrow and when stock spreads were wide, and the information share was higher for out of the money options and then for at the money options. Bali and Hovakimin (2009) found that information spilled over from KOSPI 200 index options market to the underlying stock market and noted that options trading volume was informative about future volume and volatility of the underlying stock, thus concluded that the options market generally leads the stock market. Byoun and Park (2015) also noted that the options market was efficient in its pricing, and was leading its spot counterpart in its initial phase in the KOSPI 200 index options market. Chung, Park, and Ryu (2016) added that in the KOSPI 200 index options market, fast trading showed informed trading in OTM options while it indicated noisy and uninformed trading in ITM options. Considering the futures market into the lead-lag structure between KOSPI 200 index and its options market, it was found that informed trading is relatively concentrated in the futures market rather than in the options market because the option traders are followers who respond to the spot and futures prices (Ryu, 2015). An examination of how options, futures and spot market prices were adjusted to eliminate mispricing, Ryu and Yang (2017) supported the linkage between the KOSPI 200 index futures and options markets and the fast information streams between the markets and found that price discovery happens in both derivative segments altogether and found that the options market slightly followed the futures market in adjusting price disagreements and the stock market lagged behind the derivative markets. Baltussen, Grient, Groot, Hennink, and Zhou (2012) constructed four options market measures viz. out of the money volatility skew, realized versus implied volatility spread, at the money volatility skew and change in at the money volatility skew from options on 1250 stocks traded in the USA and examined the combined predictive power of the measures. They found that publically available information in the options market was relevant for equity investors, and all the four trading strategies produced significant returns from a well investable universe of liquid stocks. Amadori, Bekkour, and Lehnert (2014) investigated the relative informational efficiency of stocks, options and credit default swaps (CDS) for European firms during the period of the global financial crisis and found that the debt market led the other two markets during the post-crisis period under the study, 
but the price discovery occurred in the options market during the pre-financial crisis period.

The price formation in the underlying market and the derivatives market are not only influenced by the price related variables, but by non-price variables like trade volume and open interest. Initial empirical studies on the lead-lag structure of the Indian stock and options market were on non-price variables in the markets. The information content of the trade volume and open interest of stock options were analyzed for price discovery in the Indian context by Srivastava (2004) and Mukharjee and Mishra (2004). Testing the information content of the price predictors developed using both the variables proved that they contained information to predict future price movements in the underlying stocks. Later, a detailed econometric examination of the leadlag structure of the NSE Nifty fifty index and futures and options on it by Debasish (2009) provided that the derivatives markets lead the stock market in India. The study also pointed out that the futures and options markets were integrated, and index call options lead the futures market and the futures lead put options market. The final conclusion of the study was that the relative transaction cost was one of the central elements causing the lead-lag relationship among the markets.

The design of the options market is to facilitate the mitigation of risk in the investment in the spot market. Therefore, theoretical expectation is that the options market and the stock market are closely associated with each other. The empirical literature on the lead-lag structure and information content of both the stock market and its derivatives counterpart appeared to provide much evidence that the stock market leads the options market, showing the fundamental strength of the stock market. A drawback of early lead-lag literature was the use of daily data, which was suffering from the non-simultaneity of closing prices in both markets. Later the introduction of the use of intraday transaction data solved this shortcoming. Options-implied prices, computed using implied volatility of the call options, were compared with actual values of the US stocks on a high-frequency level and proved that the stock market leads price changes in the options market for actively traded call options in the 1980s (Stephan \& Whaley, 1990). As this is against the theoretical expectations, Chan, Chung, and Johnson, (1993) re-examined the results, and found that no profitable lead was possible by trading in options on private information, even in the extreme out-of-themoney options, confirming the results of Stephan and Whaley (1990). They also found that the leading nature of the stocks over the options wasspurious, and was due to the price discreteness in the options market.

Even though proved otherwise in case of index options, an empirical analysis on the temporal relationship between stock options and their underlying stocks proved for those included S\&P 100 and S\&P 500 indices that stock prices led the options prices. This finding is also consistent with the trading cost hypotheses (Fleming, Ostdick, \& Whaley, 1996). Focusing on a multi-market linkage of price, volume and information, Easley, O'Hara, and Sreenivas, (1998) investigated on the predictive power of the options volume to forecast the stock prices with the presumption that the information content is evident in the trade volume rather than in the price, and proved that the options volume had no predictive power and the stock price changes led the options volume. This finding supports the fundamental function of the options market as it points out the presence of hedging related transactions in the segment. Further, Chan, Chung, and Fong (2002) investigated the lead-lag structure of options market and the stock market using the information content of the quote revisions and trade volume, based on net trade volume i.e., the difference between buyer initiated volume and seller initiated volume, and the findings were that stock net trade volume had a predictive power on subsequent stock and options quotes and the options net trade volume had no such power. But both stock and option quote revisions had a predictive capacity for subsequent quote revisions, and the options trades contain less information than stock trades. Conover and Peterson (1999) and Mazouz, Wu, and Yin (2015) found out that the stock market led the options market in case of positive news. But during the post-regulation period, no lead-lag structure was identified. The results of Conover and Peterson (1999) show that the institutional factors such as short-sale constraints and regulatory intensity may also affect relative price patterns between the stock market and options market, irrespective of the nature of the information spread. An econometric analysis on the relative intraday price discovery in German stock market and its futures and options segments during the early 1990s shows that the price discovery role was mutually shared by stock market and futures segment, leaving the options without no direct influence on the futures market and stocks and futures react faster to new information than the options market (Booth, Tse, \& So, 1999). The reason for this phenomenon was low transaction costs in the stock and futures market. Holowczak, Simaan, and Wu (2007) documented that high transaction costs and micro structural changes caused less information content in the options market of NASDAQ and NYSE and price discovery about future stock price movements took place in the stock market rather than in the options market. But, the options market became more informative when the underlying stock price experienced a large move, and the options quotes became much more informative during periods of significant option trading activities. Kim, Kim, Nam (2009) analyzed the lead-lag relationship from alternative bases like different option pricing models, moneyness of the options and the news spread in the 
Korean market, and found that the stock market leads the index options market. But, call options had a role in price discovery when the market turned bullish and put options had a role in price discovery when the market turned bearish. Further, the purpose of trading OTM options were identified as speculation rather than informed trading.

Another set of studies on the temporal relationship between the options market and its underlying spot market were around the informational efficiency of the implied volatility. Computation of the implied volatility is from the current options prices, and it is the measure of volatility that equates the theoretical options price with the actual market price of the same. The implied volatility, as defined as the measurement of the market's expectations on the future realized volatility, is capable of examining the informational efficiency of options market over the stock market. The implied volatility is said to be informational efficient when no other volatility estimation can capture any information beyond the informational content of the implied volatilities. If the options market is informational efficient, the price forecasts based on implied volatility should outperform the forecasts based on the historical returns. The informational efficiency of the implied volatility has been extensively used in Indian empirical literature on the predictability of the options prices over the stock prices. Dixit, Yadav, and Jain (2010) found that implied volatilities failed to capture all the information available in the historical returns intimating that the mispricing of options, and the options market can become efficient only when these erroneous pricings are corrected. Shaikh and Padhi $(2013$; 2015) found that the ex-ante volatility was more informative and impounded necessary information to explain the future realized return volatility while examining the causal relationship between the pairs of ex-ante and ex-post volatility of S\&P CNX Nifty index options.

\section{Implied IndeX LeVEL}

Manaster and Rendleman (1982) proposed the concept of an implied stock level for the first time while considering the ability of the options prices to predict the long term equilibrium price of the underlying stock. Cremers, Goyenko, Schultz, and Szaura (2019) considered the stock price implied from options prices as a direct and innate measure of assessment by options traders on the value of the underlying stock, and showed that forecasts based on implied index level are more accurate and consistent than estimates based on large empirically used implied volatility and options trade volume. It means, implied index level subsumes plentiful information than those contained in other variables like implied volatility and option trade volume. The options price, as defined under BSOPM, is a function of the current value of the underlying asset, the variance of the rate of return of the underlying asset, the time to expiration, the risk-free rate of interest and the strike price of the options contracts (Black \& Scholes, 1973). Using known and observed parameters in the BSOPM, except observed actual index level, the implied index level for call options and put options can be computed using following equations (1) and (2) respectively:

$$
\begin{aligned}
& P_{c, t}=\frac{K e^{-r T} \cdot N\left(d_{2}\right)+C}{N\left(d_{1}\right)} \\
& P_{p, t}=\frac{K e^{-r T} \cdot N\left(-d_{2}\right)-P}{N\left(-d_{1}\right)}
\end{aligned}
$$

where,

$$
\begin{array}{r}
d_{1}=\frac{\ln \left(P_{j, t} / K\right)+\left(r-\sigma^{2} / 2\right) T}{\sigma \sqrt{T}} \\
d_{2}=d_{1}-\sigma \sqrt{T}
\end{array}
$$

$P_{c t}$ and $P_{t p}$, are the implied index levels based on call options and put options respectively, $C$ and $P$ are actual prices of call options and put options respectively, $\mathrm{N}($.$) is cumulative normal density function,$ $P_{j, t}$ is the actual index level for call options or put options as the case may be, $K$ is the strike price of options contracts, $r$ is the risk-free rate or return, $\sigma$ is the annualized standard deviation of the rate of return of the underlying asset and $T$ is the time to maturity of options.

This process is based on the underlying logic that the implied index level is the value of the underlying index for which a constantly revised options bond portfolio would be considered as perfect substitute for the index. Assuming options are really priced according to the pricing model, it is understood that the implied index level is the assessment of the options market on the equilibrium actual index values. In simple words, the implied index level represents the cumulative expectations of participants in the options market.

\section{Data And Methodology}

The Indian stock and options markets are represented by the National Stock Exchange of India Ltd. (hereafter, NSE), as it is the largest exchange in India and the third-largest in the world in terms of the amount of transactions, where both stocks and derivatives are traded. The data on both the stock market and the options market is from the NSE Nifty 50 index, which is the flag index of NSE that includes stocks of companies from all prominent industrial sectors in India. The whole period when the options market was active in the Indian financial system i.e., from its inception, is considered for the study. In India, options were first introduced in NSE on 04 June 2001. Therefore, the data period is from 04 June 2001 to 29 March 2019. We classify options contracts into five 
categories of moneyness based on the distance between their daily spot price and strike price of the index options contracts (Debasish, 2009; Shaikh \& Padhi, 2013; Baltussen, Grient, Groot, Hennink, \& Zhou, 2012; Bakshi, Cao, \& Chen, 2000; Cassese \& Guidolin, 2004; Sehgal \& Vijayakumar, 2008; Yang, Choi, \& Ryu, 2016) using spot to strike ratio and strike to spot ratio for call and put options, respectively. Considering Pan, Shiu, \& Wu (2014)and Yang, Lee, and Ryu (2017), options are classified as DOTM when the ratio is lower than 0.925, as OTMwhen itis lower than 0.975 but not less than 0.925, as ATM when it is lower than 1.025 but not less than 0.975, as ITM when its value becomes greater than 1.025 but less than 1.075 and as DITM when it goes greater than 1.075.Due to the insufficiency of the data, the entire period cannot be considered for all the different options segments. The data period for each option segment is selected as given in Table 1. In the case of ATM call and put options, data is available for the whole period under study. But in all other cases, data are unavailable, after applying basic filters (explained below).

Table 1: Data period under study

\begin{tabular}{|c|c|c|}
\hline Moneyness & Call Options & Put Options \\
\hline ATM & $04 / 06 / 2001$ to $29 / 03 / 2019$ & $04 / 06 / 2001$ to $29 / 03 / 2019$ \\
\hline OTM & $27 / 07 / 2007$ to $29 / 03 / 2019$ & $26 / 03 / 2004$ to $29 / 03 / 2019$ \\
\hline ITM & $01 / 07 / 2005$ to $10 / 05 / 2011$ & $27 / 07 / 2007$ to $29 / 03 / 2019$ \\
\hline DOTM & $15 / 03 / 2008$ to $29 / 03 / 2019$ & $28 / 08 / 2007$ to $29 / 03 / 2019$ \\
\hline DITM & $18 / 07 / 2008$ to $19 / 07 / 2010$ & $15 / 01 / 2008$ to $29 / 03 / 2019$ \\
\hline
\end{tabular}

The time-series data for the stock market (hereafter, actual index) is easier to obtain, and daily closing values of the NSE Nifty 50 index are taken for the purpose. But, the challenge is the formation of timeseries data for the index options contracts (hereafter, implied index). There are multiple contracts with different strike prices and time to maturity, based on the same underlying asset, i.e., NSE Nifty 50 index, simultaneously traded in the options segment. The following filters are applied to arrive at a time-series representation of the options market.

- To ensure the liquidity of the selected options, only near month options (Mukharjee \& Mishra, 2004) having at least one trade on a trading day are selected (Dixit, Yadav, \& Jain, 2010).

- To avoid the variability in the implied volatility due to over liquidity during the maturing week of options, the contracts are selected with a jump to the next expiration cycle eight days prior to maturity (Srivastava, 2004; Debasish, 2009).

- Options violating lower arbitrage boundaries are filtered as they clearly violate the general properties of the options pricing model (Jiang \& Tian, 2011; Bhat \& Arekar, 2016). No evidence for upper arbitrage boundary violations are available from the Indian options market. Therefore, only those options contracts that satisfy the conditions mentioned in equations (5) and (6) are considered for further process.

$$
\begin{aligned}
& C_{t}>=\operatorname{Max}\left(0, S_{t}-K e^{-r T}\right) \\
& P_{t}>=\operatorname{Max}\left(0, K e^{-r T}-S_{t}\right)
\end{aligned}
$$

where $C_{t}$ and $P_{t}$ are actual call and put options prices for the time $t$, respectively, $S_{t}$ is the actual index value for the time $t, K$ is the strike price of options contracts, $r$ is the risk-free rate of interest, and $T$ is the time to expiry.

- All different moneyness groups, viz. ATM, ITM, OTM, DITM and DOTM, are selected for the study. From the multiple contracts remaining after applying the above filters, the one contract with the highest trade volume on the day is used to represent the day in the concerned moneyness group for the formation of time-series.

Implied index levels are calculated for the selected call and put contracts using equations (1) and (2), respectively. For the computation, the yield on 91 days Treasury Bills issued by the Reserve Bank of India $(\mathrm{RBI})$ is considered to proxy risk-free rate of interest, and number of trading days considered for annualizing the time to expiration of the options is 252. Since the index options traded in India are European in style, dividend yield is not considered while calculating the implied index level. The implied index level, as computed above, is taken to represent both the call options and the put options markets (Debasish, 2009).

For the further analysis, the stationarity property of each data series i.e., actual index level and implied index level, is tested using Augmented Dickey-Fuller (hereafter, ADF) unit root test using equation (7), with the null hypothesis that there is a unit root $(\delta=0)$, to identify the order of integration of the process.

$$
\Delta Y_{t}=\alpha+\beta t+\delta Y_{t-1}+\epsilon_{t}
$$

where $t$ is the time or trend variable.

To establish the possibility of hedging risk in the underlying spot market using derivative counterparts, it is necessary to establish that there is a long-run association among the markets. Since time-series of price data in the actual index and the implied index are 
integrated of order one, the long-run equilibrium state is established using equation (8)

$$
P_{j, t}-\hat{\beta}_{0}-\hat{\beta}_{1} P_{s, t}=\hat{\epsilon}_{o, t}
$$

where $P_{j, t}$ and $P_{s, t}$ are the contemporaneous implied index level of call options or put options and actual index level at time $t$, respectively, $\hat{\beta}_{0}$ and $\hat{\beta}_{1}$ are

$$
\begin{aligned}
& r_{s, t}=\alpha_{1}+\alpha_{s} \hat{e}_{j, t-1}+\sum_{k=1}^{n} \alpha_{11}(k) r_{s, t-k}+\sum_{k=1}^{n} \alpha_{12}(k) r_{j, t-k}+\hat{\epsilon}_{s, t} \\
& r_{j, t}=\alpha_{1}+\alpha_{j} \hat{e}_{j, t-1}+\sum_{k=1}^{n} \alpha_{21}(k) r_{s, t-k}+\sum_{k=1}^{n} \alpha_{22}(k) r_{j, t-k}+\hat{\epsilon}_{j, t}
\end{aligned}
$$

where, $r_{j, t}$ and $r_{s, t}$ are change in implied index values for call options or put options as the case may be and actual index values at time $t$, respectively.

\section{Empirical Results \& Discussion}

The descriptive statistics and normality properties of the entire data series are given in Table 2 . For both call options and put options and also for each of the moneyness groups, mean and standard deviation are reported to summarize the market movements and skewness, kurtosis and jarque-bera statistics are reported to condense the normality of the data. The whole period comprises 4436 trading days where the average actual index level is 5152.0 with a standard deviation of 2949.4, the average implied index level for call options is 5017.4 with a standard deviation of 2812.7 and the average implied index level for put options is 5240.1 with a standard deviation of 3072.0. parameters and $\hat{\epsilon}_{o, t}$ is the error that represents the deviation from the equilibrium.

Further, Following Kim, Kim, and Nam (2009), vector error correction models are used in the study to estimate the short run association between the markets using equation (9) and (10).

DOTM call options and DITM, DOTM and ITM put options show the highest average price level with minimum standard deviations, indicating that when the market reaches new heights, there are more transactions in the risky options segments. The normality properties show that actual index level and implied index level for both call options and put options and for each sub-segments are non-normal. These findings are in line with common understandings on the properties of a timed price series. The null hypothesis of normality is rejected in all cases by jarque-bera test and further analysis is conducted after data smoothening procedures. The initial inferences on the data series is that the movements of actual index and implied index levels show the presence of stochastic trend and drift in the series and they have been statistically verified while

\begin{tabular}{|c|c|c|c|c|c|c|c|c|c|}
\hline \multicolumn{3}{|c|}{ Markets } & Mean & Std. Dev. & Skewness & Kurtosis & Jarque-Bera & Prob. & Obs. \\
\hline \multirow{10}{*}{ 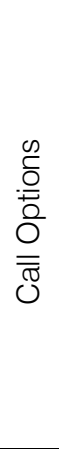 } & \multirow{2}{*}{ ATM } & Actual Index & 5152.0 & 2949.4 & 0.31 & 2.14 & 208.2 & 0.00 & 4436 \\
\hline & & Implied Index & 5014.7 & 2812.7 & 0.26 & 2.12 & 189.9 & 0.00 & 4436 \\
\hline & \multirow{2}{*}{ OTM } & Actual Index & 6810.3 & 2203.3 & 0.42 & 2.20 & 161.3 & 0.00 & 2892 \\
\hline & & Implied Index & 6524.3 & 1971.0 & 0.43 & 2.24 & 158.4 & 0.00 & 2892 \\
\hline & \multirow{2}{*}{ DITM } & Actual Index & 4282.6 & 906.3 & -0.62 & 1.90 & 55.8 & 0.00 & 489 \\
\hline & & Implied Index & 4304.7 & 882.2 & -0.65 & 1.95 & 56.7 & 0.00 & 489 \\
\hline & \multirow{2}{*}{ DOTM } & Actual Index & 6875.3 & 2221.9 & 0.36 & 2.14 & 143.9 & 0.00 & 2774 \\
\hline & & Implied Index & 6564.4 & 2024.7 & 0.47 & 2.32 & 156.7 & 0.00 & 2774 \\
\hline & \multirow{2}{*}{ ITM } & Actual Index & 4285.1 & 1098.9 & -0.11 & 1.89 & 77.6 & 0.00 & 1452 \\
\hline & & Implied Index & 4277.5 & 1089.2 & -0.13 & 1.91 & 75.5 & 0.00 & 1452 \\
\hline \multirow{10}{*}{ 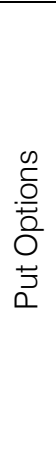 } & \multirow{2}{*}{ ATM } & Actual Index & 5152.0 & 2949.4 & 0.31 & 2.14 & 208.2 & 0.00 & 4436 \\
\hline & & Implied Index & 5240.1 & 3072.0 & 0.36 & 2.15 & 232.1 & 0.00 & 4436 \\
\hline & \multirow{2}{*}{ OTM } & Actual Index & 5903.5 & 2604.2 & 0.32 & 2.25 & 152.7 & 0.00 & 3730 \\
\hline & & Implied Index & 6015.3 & 2771.8 & 0.37 & 2.21 & 182.6 & 0.00 & 3730 \\
\hline & \multirow{2}{*}{ DITM } & Actual Index & 6875.3 & 2221.9 & 0.36 & 2.14 & 143.9 & 0.00 & 2774 \\
\hline & & Implied Index & 6865.0 & 2232.7 & 0.35 & 2.14 & 139.8 & 0.00 & 2774 \\
\hline & \multirow{2}{*}{ DOTM } & Actual Index & 6828.6 & 2200.9 & 0.41 & 2.19 & 156.4 & 0.00 & 2871 \\
\hline & & Implied Index & 6878.4 & 2354.2 & 0.36 & 2.13 & 151.8 & 0.00 & 2871 \\
\hline & \multirow{2}{*}{ ITM } & Actual Index & 6810.3 & 2203.3 & 0.42 & 2.20 & 161.3 & 0.00 & 2892 \\
\hline & & Implied Index & 6870.5 & 2275.0 & 0.39 & 2.18 & 156.0 & 0.00 & 2892 \\
\hline
\end{tabular}
the ADF was run to test unit root.

Table 2: Summary Statistics

Source: Computation of researchers

Not surprising, as Khan, Ikram, and Mehtab, (2011) pointed out along with other previous empirical observations, ADF unit root test, which was tested using equation (7), rejected the null hypothesis that there is a 
unit root in the variables, i.e., actual index level and implied index levels for both call options and put options, at level and failed to reject the same at difference, pointing out that the variables are stationary at the first difference level only. Therefore, the further analysis in this respect is designed to establish the long term association between the markets using Johansen's cointegration procedure, and to test for relative speed of information absorption among the market pairs using vector error correction model(hereafter, VECM).

Table 3: Results of ADF Unit Root test

\begin{tabular}{|c|c|c|c|c|c|c|c|c|c|}
\hline \multirow{3}{*}{ Moneyness } & \multirow{3}{*}{ Market } & \multicolumn{4}{|c|}{ Call Options } & \multicolumn{4}{c|}{ Put Options } \\
\cline { 3 - 10 } & & \multicolumn{2}{|c|}{ Level } & First Difference & \multicolumn{3}{c|}{ Level } & \multicolumn{2}{c|}{ First Difference } \\
\cline { 3 - 10 } & t stat. & Prob. & t stat. & Prob. & t stat. & Prob. & t stat. & Prob. \\
\hline \multirow{2}{*}{ ATM } & Actual Index & -2.11 & 0.54 & -62.03 & 0.00 & -2.11 & 0.54 & -62.03 & 0.00 \\
\cline { 2 - 10 } & Implied Index & -1.93 & 0.64 & -70.34 & 0.00 & -2.57 & 0.30 & -68.85 & 0.00 \\
\hline \multirow{2}{*}{ OTM } & Actual Index & -2.91 & 0.16 & -50.43 & 0.00 & -2.85 & 0.18 & -57.30 & 0.00 \\
\cline { 2 - 10 } & Implied Index & -2.86 & 0.18 & -54.64 & 0.00 & -1.57 & 0.50 & -63.37 & 0.00 \\
\hline \multirow{2}{*}{ ITM } & Actual Index & -2.08 & 0.26 & -36.09 & 0.00 & -2.91 & 0.16 & -50.43 & 0.00 \\
\cline { 2 - 10 } & Implied Index & -2.14 & 0.23 & -38.47 & 0.00 & -0.99 & 0.76 & -55.47 & 0.00 \\
\hline \multirow{2}{*}{ DOTM } & Actual Index & -0.51 & 0.89 & -49.67 & 0.00 & -2.87 & 0.17 & -50.01 & 0.00 \\
\cline { 2 - 10 } & Implied Index & -0.34 & 0.92 & -13.26 & 0.00 & -1.29 & 0.64 & -46.90 & 0.00 \\
\hline \multirow{2}{*}{ DITM } & Actual Index & -1.98 & 0.61 & -20.65 & 0.00 & -0.51 & 0.89 & -49.67 & 0.00 \\
\cline { 2 - 10 } & Implied Index & -1.96 & 0.62 & -21.67 & 0.00 & -0.58 & 0.87 & -52.99 & 0.00 \\
\hline
\end{tabular}

\section{Vi. Suitability of Options Market for HEDGING}

The derivative counterparts of cash markets can be used suitably for hedging, only when they are closely associated in the long run. The Johansen's cointegration test provides for examining the long-run equilibrium relationship between two price series. From Table 4, it is clear that the null hypothesis that there is no cointegration existing between the stock market and its options counterparts has been rejected in all the cases and the alternate hypothesis on the presence of at most one cointegration existing between the markets are accepted. It shows that the association between the stock market and the call and put options markets is developed in such a way that the price movements are reverted to an equilibrium position in the long-run. If two markets show such a relationship in the long-run, it stands for a close integration among them. Debasish(2009) has already documented from the Indian context that there exists a cointegrating relationship between the stock market and its options counterparts. Fleming, Ostdick, and Whaley (1996) discussed the presence of the cointegrating relationship as it is a result of arbitrage relationship existing between the market pairs, which makes the rebalancing of equilibrium state possible between the market pairs. When cointegration is present, the lagged differences between the cointegrating pairs of variables provide superior information to those contained in the finite number of changes in each variable. This larger information can be captured by the use of an error correction term, which is derived using the VECM that examines short-run dynamic relationship between the markets.

Table 4: Long run relationship among stock and options markets (Johansen's Cointegration Results)

\begin{tabular}{|c|c|c|c|c|c|c|c|c|c|}
\hline \multirow{2}{*}{ Moneyness } & \multirow{2}{*}{$\mathrm{H}_{0}$} & \multicolumn{4}{|c|}{ Call Options } & \multicolumn{4}{c|}{ Put Options } \\
\cline { 3 - 10 } & Statistic & Prob. & $\begin{array}{c}\text { Max-Eigen } \\
\text { Statistic }\end{array}$ & Prob. & $\begin{array}{c}\text { Trace } \\
\text { Statistic }\end{array}$ & Prob. & $\begin{array}{c}\text { Max-Eigen } \\
\text { Statistic }\end{array}$ & Prob. \\
\hline \multirow{2}{*}{ ATM } & $\mathrm{r}=0$ & 78.89 & 0.00 & 77.64 & 0.00 & 36.06 & 0.00 & 34.57 & 0.00 \\
\cline { 2 - 11 } & $\mathrm{r} \leq 1$ & 1.25 & 0.26 & 1.25 & 0.26 & 1.49 & 0.22 & 1.49 & 0.22 \\
\hline \multirow{2}{*}{ OTM } & $\mathrm{r}=0$ & 69.81 & 0.00 & 69.17 & 0.00 & 54.15 & 0.00 & 52.18 & 0.00 \\
\cline { 2 - 10 } & $\mathrm{r} \leq 1$ & 0.64 & 0.42 & 0.64 & 0.42 & 1.96 & 0.16 & 1.96 & 0.16 \\
\hline \multirow{2}{*}{ ITM } & $\mathrm{r}=0$ & 55.39 & 0.00 & 49.19 & 0.00 & 60.58 & 0.00 & 60.02 & 0.00 \\
\cline { 2 - 11 } & $\mathrm{r} \leq 1$ & 6.20 & 0.18 & 6.20 & 0.18 & 0.57 & 0.45 & 0.57 & 0.45 \\
\hline \multirow{2}{*}{ DOTM } & $\mathrm{r}=0$ & 134.07 & 0.00 & 133.83 & 0.00 & 105.46 & 0.00 & 105.04 & 0.00 \\
\cline { 2 - 10 } & $\mathrm{r} \leq 1$ & 0.23 & 0.63 & 0.23 & 0.63 & 0.42 & 0.52 & 0.42 & 0.52 \\
\hline \multirow{2}{*}{ DITM } & $\mathrm{r}=0$ & 44.45 & 0.00 & 43.66 & 0.00 & 146.95 & 0.00 & 146.81 & 0.00 \\
\cline { 2 - 10 } & $\mathrm{r} \leq 1$ & 0.79 & 0.37 & 0.79 & 0.37 & 0.14 & 0.71 & 0.14 & 0.71 \\
\hline
\end{tabular}


When the stock market and options market are cointegrated, it means that there is a long run close association between the markets. This close association demonstrates the ability of both the markets to move in tandem at all times. This long-run co-movement is due to the capability of the markets to adjust back from deviations from this equilibrium, which can be measured effectively by the VECM. The error correction term, also known as the speed of adjustment coefficient, explains the ability of the markets to respond to the new information coming into the capital market.

Table 5: Short run relationship among stock and options markets (VECM Estimation)

\begin{tabular}{|c|c|c|c|c|c|}
\hline \multirow{2}{*}{ Moneyness } & \multirow{2}{*}{ Market } & \multicolumn{2}{|c|}{ Call Options } & \multicolumn{2}{c|}{ Put Options } \\
\cline { 3 - 6 } & & Coeff. & Prob. & Coeff. & Prob. \\
\hline \multirow{2}{*}{ ATM } & Actual Index & 0.004 & 0.689 & -0.009 & 0.381 \\
\cline { 2 - 6 } & Implied Index & -0.052 & 0.000 & -0.042 & 0.000 \\
\hline \multirow{2}{*}{ OTM } & Actual Index & -0.009 & 0.492 & 0.011 & 0.223 \\
\cline { 2 - 6 } & Implied Index & -0.080 & 0.000 & -0.040 & 0.001 \\
\hline \multirow{2}{*}{ ITM } & Actual Index & 0.001 & 0.970 & -0.016 & 0.560 \\
\cline { 2 - 6 } & Implied Index & -0.126 & 0.000 & -0.127 & 0.000 \\
\hline \multirow{2}{*}{ DOTM } & Actual Index & 0.001 & 0.929 & -0.008 & 0.391 \\
\cline { 2 - 6 } & Implied Index & -0.186 & 0.000 & -0.164 & 0.000 \\
\hline \multirow{2}{*}{ DITM } & Actual Index & -0.075 & 0.364 & -0.028 & 0.562 \\
\cline { 2 - 6 } & Implied Index & -0.393 & 0.000 & -0.290 & 0.000 \\
\hline
\end{tabular}

Source: Computation of researchers

Table 5 reports the results of VECM tests about the relative rate of information absorption in the pricing of stocks as well are options contracts traded in the stock market and options market in India. At first, the direction of the price discovery process was looked into, and it is noted that only a unidirectional cause and effect relationship is existing among the market pairs. It means when the options market responds to new information and adjusts itself to the long term equilibrium, the stock market shows no such movements. Finally, the significance of the error correction term is examined. It is noted that the DITM call and put options markets respond $39.3 \%$ and $29.0 \%$ to the new information. The highest level of information absorption is taken place there. The DOTM options also show significant information absorption rate i.e., $18.6 \%$ and $16.4 \%$ for call and put options, respectively. The ITM options respond approximately $12 \%$ to the new information. $8 \%$ of the information absorption takes place in OTM call options market and ATM call options absorbs $5 \%$ of the new information. ATM and OTM put options capture about $4 \%$ of the information coming into the market system afresh. The VECM results show that these relationships are statistically significant too. But the stock market shows no significant information absorption when compared with the options segment. In other words, when the stock market hesitates to respond to the new information being flown into the market, the options market adjusts itself to the equilibrium position within a day's time. The results especially indicate the informational role of DITM and DOTM options, which absorb substantial information rather than the stock market. Because DITM and DOTM options are substantially present only when the stock market is performing sound with the realization of new heights in the price level, the informational role played by them in Indian market goes extensively consistent with the findings of Ren, Ji, Cai, Li, and Jiang, (2019) who noted that the index option market leads the stock index market in China when the index stands stable and uptrend. It is an indication that the relative informational efficiency among different market components is subject to market conditions and other dynamics.

Even though the options markets are designed to support the functioning of the underlying stock market, the theoretical expectations framed through early empirical evidences of Anthony (1988) Manaster and Rendleman (1982) and Bhattacharya (1987) are that the options market may lead the price discovery process in the stock market. The Indian evidence is also in support of the findings of the study. Srivastava (2004) and Mukharjee and Mishra (2004) noted the price discovery role of the information content of the trade volume and open interest of stock options, and Debasish (2009) provided that the derivatives markets lead the stock market in India. But the results contradict with Mallikarjunappa and Afzal (2008), Dixit, Yadav, and Jain (2010), Shaik and Padhi (2013; 2015), that provided that the Indian options market measures fail to capture all relevant information for forecasting price movements in the stock market. But the current results do not claim that it contains all relevant information for stock market forecasting, rather it aims to provide directional information to the market participants on where to approach for information useful for decision making in connection with hedging transactions. From global literature, the results are in line with the findings of Lee and Nayar (1993) who remarked that cash, futures and options segments on S\&P 500 index in the USA are cointegrated, Kyriacou and Sarno (1999) who showed 
that there exists a simultaneous temporal relationship between spot market and its derivative counterparts in FTSE 100 index in the U.K, Bali and Hovakimin (2009) who found that information spilled over from KOSPI 200 index options market to the underlying stock market, Byoun and Park (2015) who noted that KOSPI 200 index options market was leading its spot counterpart in its initial phase and Ryu and Yang (2017) who found that the price discovery happens in both futures and options segments altogether and concluded that the stock market lagged behind the derivative markets. The results of the current study gain support from Fleming, Ostdick, and Whaley (1996), Holowczak, Simaan, and Wu (2007), Kim, Kim, and Nam (2009), Ahn, Bi, and Sohn (2018) and Du and Fung (2018) which rigorously employed different techniques and finally concluded this nature of the options market.

\section{Vil. Conclusion}

The integration of the hedging instrument with the asset to be hedged is considered as the base for the suitability of the hedging instrument. The present study is to enquire about the possibilities for hedging the risk of investments in the Indian stock market using options contracts on it. The Indian stock market and the options markets are represented by the NSE Nifty fifty index and the Nifty fifty index options for the period from 2001 to 2019. Both call and put options are considered with all moneyness categories viz. ATM, OTM, ITM, DITM and DOTM. At first, it is found that the stock market and both the call and put options markets are cointegrated, and it shows that the Indian options markets are suitable for hedging risks involved in the stock market investments. Apart from that, the price formation relationship among the market pairs is considered, and it is found that the price formation through information absorption takes place in the options market irrespective of moneyness categories and other market situations.

Further, even though the trade volume is higher for ATM options and OTM options, the DITM and DOTM options that are not traded much absorbs more information in the market. In other words, when the options sellers and buyers take the risk of contracts being expired at extreme values, they use all information to price the same more accurately. It means the implied index level, whichrepresents the options markets' expectation about future movements in the actual index level, is more accurate in case of extreme options pay off structures. To conclude, the stock market and options market are integratedin all the ten market combinations, and the Indian options markets are suitable for hedging. Moreover, looking at the extreme moneyness options contracts, the future movements of the stock market can be identified.

\section{References Références Referencias}

1. Ahn, K., Bi, Y., \& Sohn, S. (2018). Price discovery among SSE 50 Index-based spot, futures and options markets. Journal of Futures Market, 01-22.

2. Amadori, M. C., Bekkour, L., \& Lehnert, T. (2014). The Relative Informational Efficiency of Stocks, Options and Credit Default Swaps during the Financial Crisis. The Journal of Risk Finance, 510532.

3. Amin, K. I., \& Lee, C. M. (1997). Option Trading, Price Discovery and Earnings News Dissemination. Contemporary Accounting Research, 153-192.

4. Ammann, M., \& Herriger, S. (2002). Relative Implied Volatility Arbitrage with Index Options. Financial Analysts Journal, 42-55.

5. Anthony, J. H. (1988). The Interrelation of Stock and Options Market Trading - Volume Data. The Journal of Finance, 949-964.

6. Bakshi, G., Cao, C., \& Chen, Z. (2000). Do Call Prices and Underlying Stock Always Move in the Same Direction? The Review of Financial Studies, 549-584.

7. Bali, T. G., \& Hovakimin, A. (2009). Volatility Spreads and Expected Stock Returns. Management Science, 1797-1812.

8. Baltussen, G., Grient, B. V., Groot, W. D., Hennink, E., \& Zhou, W. (2012). Exploiting Option Information in the Equity Market. Financial Analysts Journal, 56-72.

9. Bhat, A., \& Arekar, K. (2016). Empirical performance of Black - Scholes and GARCH option pricing models during turbulent times: The Indian evidence. International Journal of Economics and Finance, 123-136.

10. Bhattacharya, M. (1987). Price changes of related securities: The case of call options and stocks. Journal of Financial and Quantitative Analysis, 1-15.

11. Black, F., \& Scholes, M. (1972). The Valuation of Option Contracts and a Test of Market Efficiency. The Journal of Finance, 399-417.

12. Black, F., \& Scholes, M. (1973, May - June). The Pricing of Options and Corporate Liabilities. Journal of Political Economy, 637-654.

13. Booth, G. G., So, R. W., \& Tse, Y. (1999). Price Discovery in the German Equity Index Derivatives. The Journal of Futures Markets, 619-643.

14. Booth, G. G., Tse, Y., \& So, R. W. (1999). Price discovery in the German equity index derivatives markets. The Journal of Futures Market, 619-643.

15. Boyle, P. P., Byoun, S., \& Park, H. Y. (2002). The Lead Lag Relationship between Spot and Option Markets and Implied Volatility in Option Prices. Research in Finance, 269-284.

16. Byoun, S., \& Park, H. Y. (2015). Arbitrage Opportunities and Efficiency of an Option Market in 
its Initial Stage: The Case of KOSPI 200 Options in Korea. Research in Finance, 269-301.

17. Caralla, L., \& Mammola, P. (2000). Empirical Tests of Efficiency of the Italian Index Options Market. Journal of Empirical Finance, 173-193.

18. Cassese, G., \& Guidolin, M. (2004). Pricing and Informational Efficiency of the MIB30 Index Options Market: An Analysis with High Frequency Data. Economic Notes by Banca Monte Dei Paschi di Siena SpA, 275-321.

19. Chakravarthy, S., Gulen, H., \& Mayhew, S. (2004). Informed Trading in Stock and Option Market. The Journal of Finance, 1235-1257.

20. Chan, K., Chung, Y. P., \& Fong, W.-N. (2002). the informational Role of Option Volume. The Review of Financial Studies, 1049-1075.

21. Chan, K., Chung, Y. P., \& Johnson, H. (1993). Why Option Prices Lag Stock Prices: A Trading Based Explanation. The Journal of Finance, 1957-1967.

22. Chung, K. H., Park, S. G., \& Ryu, D. (2016). Trade durations, informed trading and options moneyness. nternational Review of Economics and Finance, 395-411.

23. Conover, C. M., \& Peterson, D. R. (1999). The Lead Lag Relationship between the Option and Stock Markets Prior to Substantial Earnings Surprises and the Effect of Security Regulation. Journal of Financial and Strategic Decisions, 41-52.

24. Cremers, M., Goyenko, R., Schultz, P., \& Szaura, S. (2019). Informed Trading of Options, Option Expiration Risk, and Stock Return Predictability. SSRN, 1-52. Retrieved from https://ssrn.co $\mathrm{m} / \mathrm{abstract}=3347194$

25. Debasish, S. S. (2009). An econometric analysis of the lead-lag relationship between India's NSE Nifty and its derivative contracts. The Journal of Risk Finance, 350-364.

26. Dicle, M. F., Beyhan, A., \& Yao, L. J. (2010). Market Efficiency and International Diversification: Evidence from India. International Review of Economics and Finance, 313-339.

27. Dixit, A., Yadav, S. S., \& Jain, P. (2010). Informational Efficiency of Implied Volatilities of S\&P CNX Nifty Index Options: A Study in Indian Securities market. Journal of Advances in Management Research, 32-57.

28. Dixit, A., Yadav, S. S., \& Jain, P. K. (2009). Violation of lower boundary condition and market efficiency: An investigation into the Indian options market. Journal of Derivatives \& Hedge Funds, 03-14.

29. Du, B., \& Fung, S. (2018). Directional information effects of options trading: Evidence from the banking industry. Journal of International Financial Markets, Institutions \& Money, 149-168.

30. Easley, D., O' Hara, M., \& Sreenivas, P. (1998). Option Volume and Stock Prices: Evidence on
Where Informend Traders Trade. The Journal of Finance, 431-465.

31. Fama, E. (1970). Efficient Capital Markets: A Review of Theory and Empirical Work. Journal of Finance, 383-417.

32. Fleming, J., Ostdick, B., \& Whaley, R. E. (1996). Trading Costs and Relative Rates of Price Discovery in Stock, Futures and Option Markets. The Journal of Futures Market, 353-387.

33. Gupta, R., \& Basu, P. K. (2007). Weak form Efficiency in Indian Stock Market. International Business and Economic Research Journal, 57-64.

34. Harvey, C. R., \& Whaley, R. E. (1992). Market Volatility Prediction and the Efficiency of the S\&P 100 Index Option Market. Journal of Financial Economics, 42-73.

35. Hasbrouk, J. (1995, September). One Security, Many Markets: Determining the Contribution to Price Discovery. The Journal of Finance, I (4), 1175-1199.

36. Hentze, S., \& Seiler, M. J. (2000). An Examination of the Lead / Lag Relationship Between the Option Market and the Stock Market: Where Do We Stand? Quarterly Journal of Business and Economics, 35-48.

37. Holowczak, R., Simaan, Y. E., \& Wu, L. (2007). Price Discovery in the US stock and stock option markets: A portfolio approach. Springer Science + Business Media, 1-29.

38. Hull, J. C., \& Basu, S. (2016). Options, Futures and Other Derivatives $(9$ ed.). New Delhi: Pearson Education India.

39. Jain, P., Vyas, V., \& Roy, A. (2013). A Study on Weak Form of Market Efficiency during the Period of Global Financial Crisis in the form of Random Walk on Indian Capital Market. Journal of Advances in Management Research, 122-138.

40. Jiang, G. J., \& Tian, Y. S. (2011). A Random Walk Down the Options Market. The Journal of Futures Market, 505-535.

41. Joshi, D. J. (2012). Testing Market Efficiency of Indian Stock Market. International Journal of Scientific and Research Publication, 1-4.

42. Khan, A., Ikram, S., \& Mehtab, M. (2011). Testing Weak form Market Efficiency of Indian Capital Market: A Case of National Stock Exchange (NSE) and Bombay Stock Exchange (BSE). African Journal of Marketing Management, 115-127.

43. Kim, S., Kim, I. J., \& Nam, S. O. (2009). The Lead Lag Relationship between Stock Index Options and the Stock Index Market; Model, Moneyness and News. International Journal of Managerial Finance, 311-332.

44. Kumar, R., Sarin, A., \& Shastri, K. (1995). The Impact of Index Options on the Underlying Stock: The Evidence from the listing of Nikkei Stock Average Options. Pacific Basin Finance Journal, 303-317. 
45. Kyriacou, K., \& Sarno, L. (1999). The temporal relationship between derivatives trading and spot market volatility in the U.K.: Empirical analysis and Monte Carlo evidence. The Journal of Futures Markets, 245-270.

46. Lee, J. H., \& Nayar, N. (1993). A Transactions Data Analysis of Arbitrage between Index Options and Index Futures. The Journal of Futures Markets, 889-902.

47. Lee, Y.-H., \& Wang, D. K. (2016). Information content of investor trading behaviour: Evidence from Taiwan index options market.

48. Mallikarjunappa, T., \& Afsal, E. M. (2008). The impact of derivatives on stock market volatility: A study of the Nifty index. Asian Academy of Management Journal of Accounting and Finance, 43-65.

49. Manaster, S., \& Rendleman, R. J. (1982). Option prices as predictors of equilibrium stock prices. Journal of Finance, 1043-1057.

50. Mazouz, K., Wu, Y., \& Yin, S. (2015). Trading Activity in Options and Stock around Price - Sensitive News Announcements. Journal of Futures Market, 11731194.

51. Mukharjee, K. N., \& Mishra, R. (2004). Impact of open interest and trading volume in Option Market on Underlying Cash Market: Empirical Evidence from Indian Equity Options Market. International Conference on Business and Finance.

52. Oprean, C. (2012). Testing the Financial Market Informational Efficiency in Emerging States. Review of Applied Socio-Economic Research, 181.

53. Pan, G. -G., Shiu, Y. -M., \& Wu, T. -C. (2014). The effects of stochastic volatility and demand pressure on the monotonicity property violations. The Journal of Derivatives, 90-102.

54. Ren, F., Ji, S.-D., Cai, M.-L., Li, S.-P., \& Jiang, X.-F. (2019). Dynamic lead-lag relationship between stock indices and their derivatives: A comparative study between Chinese mainland, Hong Kong and US stock markets. Physica A: Statistical Mechanics and its Applications, 709-723.

55. Ryu, D. (2015). The information content of trades: An analysis of KOSPI 200 index derivatives. The Journal of Futures Market, 201-221.

56. Ryu, D. (2016). Considering all Microstructure Effects: the Extension of a Trade Indicator Model. Economic Letters, 01-05.

57. Ryu, D., \& Yang, H. (2017). Price disagreements and adjustments in index derivatives markets. Economic Letters, 104-106.

58. Sehgal, S., \& Vijayakumar, N. (2008). Determinants of Implied Volatility Function on the Nifty Index Options Market: Evidence from India. Asian Academy of Management Journal of Accounting and Finance, 45-69.
59. Shaikh, I., \& Padhi, P. (2013). On the Linkages among Ex-ante and Ex-post Volatility: Evidence from NSE Options Market (India). Global Business Review, 487-505.

60. Shaikh, I., \& Padhi, P. (2015). On the Relationship of Ex-ante and Ex-post Volatility: A Sub-period Ananlysis of S\&P CNX Nifty Index Options. Journal of Emerging Market Finance, 140-175.

61. Srivastava, S. (2004). Informational Content of Trading Volume on Open Interest: An Empirical Analysis of Stock Option Market in India. SSRN Electronic Journal. 10.2139/ssrn.606121, 01-26.

62. Stakic, N., Jovancai, A., \& Kapoor, P. (2016). the Efficiency of the Stock Market in Serbia. Journal of Policy Modeling, 156-165.

63. Stephan, J. A., \& Whaley, R. E. (1990). Intraday Price Change and Trading Volume Relations in the Stock and Stock Option Markets. The Journal of Finance, 191-219.

64. Yang, H., Choi, H. -S., \& Ryu, D. (2016). Option market characteristics and price monotonicity violations. The Journal of Futures Market , 01-26.

65. Yang, H., Lee, J., \& Ryu, D. (2017). Market Depth, Domestic Investors and Price Monotonicity Violations. Applied Economics Letters, 01-05. 